\title{
Measuring the Effect of Child Benefit on Household Expenditures: Evidence from Canadian Households' Survey Data
}

\author{
Jason Adams, Sid Ali Amedah, Maxime Fougère \\ Employment and Social Development, Gatineau, Canada \\ Email: sidali.amedah@hrsdc-rhdcc.gc.ca, jason.adams@hrsdc-rhdcc.gc.ca, maxime.fougere@hrsdc-rhdcc.gc.ca
}

How to cite this paper: Adams, J., Amedah, S. A., \& Fougère, M. (2020). Measuring the Effect of Child Benefit on Household Expenditures: Evidence from Canadian Households' Survey Data. Open Journal of Social Sciences, 8, 44-58.

https://doi.org/10.4236/jss.2020.86005

Received: April 29, 2020

Accepted: May 30, 2020

Published: June 2, 2020

Copyright ( 2020 by author(s) and Scientific Research Publishing Inc. This work is licensed under the Creative Commons Attribution International License (CC BY 4.0).

http://creativecommons.org/licenses/by/4.0/

\begin{abstract}
This study examines the effects of the Canada Child Benefit on household expenditures. Estimation of child benefit impact on household expenditure is challenging since benefit and household income may be endogenously determined. Relying on permanent income hypothesis and based on Engel's approach, findings suggest that spending patterns vary by household composition and income, but overall results indicate that receipt of this benefit is associated with a significant increase in households' wellbeing. More specifically, expenditure elasticities estimates indicate that spending on child care for households receiving higher proportions of the benefit is the most sensitive spending to any change in household permanent income, which may indicate the existence of financial constraints for those households that prevent them from maximizing their utility. Similarly, spending on school-related items for those receiving lower proportions also represents a sensitive spending.
\end{abstract}

\section{Keywords}

Child Benefit, Permanent Income, Engel's Approach, Elasticity

\section{Introduction}

Evidence that early child development experiences set the foundation for lifelong learning, skills acquisitions, behaviour, health, and wellbeing, has pushed many countries to implement child benefit systems in different forms such as tax credit, tax deduction or direct transfer, under different eligibility conditions, either universal or targeted towards some vulnerable children. However, they all aim to guarantee a certain minimum level of wellbeing for children and their families. The long term outcomes of such interventions are to improve the educational 
attainments and the physical and mental health of these children, and eventually increase their income and social mobility. If the child benefit is sizeable, a significant positive impact on fertility is also expected.

In Canada, a new universal child benefit system, the Canada Child Benefit (CCB), was introduced in July 2016 with the purpose of helping families with children under the age of eighteen with the cost of raising their children. The $\mathrm{CCB}$ is a tax-free monthly benefit that replaces existing systems, such as the Canada Child Tax Benefit, Universal Child Care Benefit, and National Child Benefit Supplement (NCBS) programs.

The CCB also provides an increased level of generosity, where under the new comprehensive benefit, nine out of ten families were also receiving more per month than under the previous series of benefits (Department of Finance Canada, 2018). It has also been found to decrease low-income rates among both couples with children and single parent households (Harding, 2018). Since its introduction, the amount of benefit provided by the CCB has been revised to account for the increase of the cost of living. The benefit amount phases out for households at the higher end of the income distribution, which makes the CCB better targeted to low-, modest- and middle-income families with children.

The Bank of Canada has attributed continued strength in household spending into 2017 at least partially to the introduction of the CCB (Bank of Canada, 2017). Brown \& Tarasuk, 2019 find that food insecurity has more decreased for households with children since the introduction of the CCB, compared to households without children.

Estimation of child benefit impact on household expenditure is challenging since benefit and household income may be endogenously determined, because child benefit income increases households' unearned income and therefore may have an impact on labour supply decisions.

The distinction between permanent and non-permanent incomes (Friedman, 1957) is important in determining the real effects of any cash transfer policy. According to economic theory, households consume not in response to current income, but in response to their expectation of longer-term income, i.e. permanent income, that is not directly observed but could be measured by total expenditures.

A simple way of measuring the impact of cash transfer on household's expenditure could be derived from Engel's law (Engel, 1857), i.e. the inverse relationship of income to spending on food as a proportion of income. Based on this "law", it could be argued that the proportion of income a household spends on basic needs (food, clothing, shelter, etc.) can be considered as a quantifiable indicator of its standard of living. Using this indicator, households spending the same proportion of their income on basic needs could be considered to have similar standard of living. Also, any decrease of this proportion over time may indicate an increase of the household's wellbeing.

The contribution of this paper is to propose a simple effective alternative approach to measure child benefit impact on households' consumption and well- 
being, which relies on the permanent income hypothesis and Engels' law.

We use cross sectional data from the Survey of Household Spending (SHS), conducted annually by Statistics Canada to examine the potential microeconomic effects of the CCB on Canadian household spending behaviour among a number of different expenditure categories. First, we compare the share of different child-related expenditures with respect to total expenditures before and after the introduction of the new CCB for different household types with children.

We then propose to estimate a variation of the Working-Leser model which relates the proportion of consumption on any given expenditure to the logarithm of the permanent income measured by total expenditures. The model also includes the household size and potential confounding factors. We estimate this model for three groups of households with children under 18: CCB-eligible to receive the maximum amount, $\mathrm{CCB}$-eligible to receive the phase-out portion, and the non-CCB eligible households.

Patterns varied based on household composition and income: couple households receiving the full CCB generally increased the proportion spent on child care, and recreational activities and toys, and decreased the proportion spent on food and clothing. Single parents receiving the full CCB have seen an increase in the proportion of total spending on child care and a decrease in the proportion spent on food, clothing, and shelter, and out-of-pocket health expenses.

More specifically, expenditure elasticities estimates indicate that spending on child care for households receiving higher proportions of the benefit is the most sensitive spending to any change in household permanent income, which indicate the existence of financial constraints for households that prevent them from maximizing their utility. Similarly spending on school-related items for those receiving lower proportions also represent a sensitive spending.

An important indirect impact of the $\mathrm{CCB}$ on households' wellbeing is through fertility rates, but this outcome cannot be captured here. Furthermore, some households may save the CCB for their children's post secondary education, such as investing in Registered Education Saving Plans (RESPs).

This paper proceeds as follows: A literature review is presented in Section 2. The data and empirical strategy are presented in Section 3; estimation results are provided in Section 4; and the paper concludes with some remarks in Section 5.

\section{Related Literature}

An extensive literature has established a positive association between household financial resources and a range of wider outcomes for children such as lifelong learning, skills acquisitions, behaviour, health, and wellbeing. The literature is clear about the positive impact of family resources on children outcomes, especially at early years. Findings from papers that examined the link between children-related expenditures and family income varies by household and expenditures types. 
Cunha and Heckman (2007) estimate an economic model of skill formation and present evidence on the importance of permanent family income at early years. Their findings rationalize the evidence on the importance of early childhood environments on adult health (Barker 1998; Case et al. 2005; Braga et al. 2019) and also the evidence that stocks of health skills raise the productivity of schooling (Bhargava, 2008).

Permanent family income has a bigger impact for children from low-income families in their early years (Dahl \& Lochner, 2012; Tominey, 2010). Ginja (2010) examined the link between family income shocks and investments in children education. Findings indicate that expenses related to children education responds less to shocks than other household expenditures.

Several papers measured the impact of government child benefit on different children outcomes. Black et al. (2012) exploit the fact that in Norway there is a sharp discontinuity in the eligibility for child care subsidies. Using administrative data on the entire Norwegian population, they compare families just below and just above the cut-off for subsidies. They found a significant effect of child care subsidies on children's educational outcomes, and more specifically that income makes more difference for families at the lower end of the income distribution.

González (2013) uses regression discontinuity design to identify the causal effects of a universal child benefit in Spain. She did not find any significant effect on directly child-related goods and services or on overall family's expenditure or consumption. Using variation in child benefits across provinces, time, and family type, Milligan \& Stabile (2011) examined outcomes spanning test scores, mental health, physical health, and deprivation measures. The findings suggest that child benefit programs in Canada had significant positive effects on these tests scores.

Hoynes et al. (2015) find a link between the Earned Income Tax Credit in the U.S. the health of infants through spending on prenatal care, as well as a decrease in parental spending on smoking. Also examining this tax credit, Hamad and Rehkopf (2016) use an instrumental variable approach to find a statistically significant effect on the behavioural development of children as the amount of tax credit increases.

Researchers and evaluators are more interested in long term outcomes rather than short term outputs. Only few papers considered the specific link between children-related expenditures and family financial resources, i.e. how family income or transfer programs achieve these long term outcomes.

Jones et al. (2019) examined how families spend Canada's NCBS child benefit by simulating the amount of benefit likely received by eligible families. They exploit the fact that this benefit varied between 1999-2009 over time and across provinces, to address potential endogeneity bias. However, their model does not address the endogeneity of the omitted family income variable that is endogenously determined because child benefit income increases households' unearned 
income and therefore may have an impact on labour supply decisions. Findings suggest that additional benefit leads to increased spending on education, recreation, and food in stores for households in the lower end of the income distribution. Another study by Kooreman (2000) which also does not address the endogeneity of income found that for some groups of households in the Netherlands, would spend more on clothing for children which applies in particular to two-parent families.

Another study by Gregg et al. (2006) examines changes in expenditure patterns and ownership of durable goods for low- and higher-income families in the U.K. They found that reforms to child benefits helped children from low-income families closing the gap with more affluent families in spending on housing, utilities, food, clothing, leisure goods and services, and travel, and more specifically that expenditures on child-related items are increasing faster than expenditures on other items.

\section{Data and Methodology}

In order to estimate the outcomes of family income or child benefits, different methods have been used in the literature, including natural experiments and quasi-experiments, instrumental variables and fixed effect methods to address potential endogeneity bias of family income, among other techniques.

Estimation of child benefit direct impact on household expenditure is challenging since benefit and household income may be endogenously determined because child benefit income increases households' unearned income and therefore may have an impact on labour supply decisions, through two channels. First, the CCB may allow relaxing the child care cost constraint for some households facing financial constraints, and thus may incite those parents to change their labour supply decision, along the extensive margin or at the intensive margin in order to maximize their utility. Second, in opposite, the CCB may incite some households' parents who are at the lower end of the income distribution for which the benefit represents an important part of their income to renounce to earn additional income. However, this effect would be mitigated since the CCB has no explicit or implicit tax, i.e. does not reduce earned income or any other government benefit.

The distinction between permanent and non-permanent incomes (Friedman, 1957), is important in determining the real effects of any cash transfer policy. According to economic theory, households consume not in response to current income, but in response to their expectation of longer-term income, i.e. permanent income, that is not directly observed but could be measured by total expenditures. A household's propensity to consume depends upon a confidence in long-term financial prospects, which, in many circumstances, a temporary cash transfer affects mostly households with liquidity constraints, i.e. households at the lower end of the income and wealth distributions.

A simple way of measuring the impact of cash transfers on a household's ex- 
penditure could be derived from Engel's law (Engel, 1857), i.e. the inverse relationship of income to spending on food as a proportion of income.

Based on this principle, it could be argued that the proportion of income a household spends on basic needs (food, clothing, shelter, etc.) can be considered as a quantifiable indicator of its standard of living. Using this indicator, families spending the same proportion of their income on basic needs could be considered to have similar standards of living. Also, any decrease of this proportion overtime may indicate an increase of the household wellbeing. Thus, an increase of the proportion of non-basic goods (superior goods) has also a positive effect on household wellbeing. Finally, based on Engel's law, movements in the share of a given necessity good expenditure could be considered as a measure of a change in wellbeing, which would help inform on the impact of CCB receipt on households' wellbeing.

\subsection{Data}

We use cross sectional microdata from the SHS, which contains detailed information on household expenditures and information on the income of household members based on personal income tax data. The SHS also contains information on demographic characteristics of Canadian households, and a range of household expenditure data. The categories of expenditures being examined in this project and descriptive breakdowns of the categories can be found in Annex A.

The SHS accounts for spending over the last two weeks to twelve months, depending on the expenditure category. The CCB was not yet in effect for the first half of the 2016 cycle of the survey, and even for those who completed the SHS in the last half of 2016, the expenditure reference period may not overlap with the period of CCB receipt. For this reason, the 2016 cycle of the survey is not used in the descriptive analysis. However, there is a full year of CCB receipt captured in the 2017 cycle. The descriptive analysis carried out here is based on the 2015 and 2017 samples of CCB-eligible survey respondents, i.e. those households with at least one child under eighteen years of age. They are split into three categories based on the calculated amount of the CCB a household is eligible to, using the 2016 CCB calculation rules: those who are receiving the full $\mathrm{CCB}$ amount, those who are receiving a partially phased-out amount, and those who are not receiving any benefit.

Although the CCB was not in effect before 2016, households from earlier survey cycles are categorized based on whether they would have likely received the full amount, a partial amount, or no CCB based on their household-adjusted net income. We also consider typical households including lone-parent and two-parent households with at least one child under eleven or under six ${ }^{1}$. For reference and to give an idea of the amount of the Canadian population represented in this research, the total sample used for 2017 represents approximately 2,696,824 households comprised of couples with children, and 400,677 ${ }^{1}$ The age ranges in these subsamples were chosen to better capture changes in certain categories of expenditures that are more age-specific, such as child care. 
households of single parents.

\subsection{Empirical Strategy}

The unit of analysis is a household with at least one child under eighteen years old. The descriptive analysis consists of estimating means of different expenditures categories and proportions of households spending a positive amount on these categories, for the years before and after the introduction of the CCB. Three indicators are examined for each expenditure category: per child expenditure in constant dollar, the percentage of households that have some positive amount of expenditure, and the per child expenditure as a percentage of total expenditure. Statistical tests are performed to test whether the estimated means and proportions from 2017 are statistically significantly greater than or less than those from 2015, depending on how one would expect the expenditure category and the indicator to be affected by the introduction of the CCB. Although this descriptive analysis may be capturing the effects of other factors on spending, this can be mitigated to some degree by comparing changes between those receiving the CCB with those not receiving it.

Formally, to control for potential confounding factors, our modeling framework consists in a simple linear regression model which allows the estimation of the expenditure elasticities using a pooled data comprised of the SHS cycles from 2010 to 2017. This model is a variation of the Working-Leser model of Working (1943) and Leser (1963) relating the natural logarithm of total expenditure of a given household to the share of its expenditure allocated to certain goods or services.

$$
s=\alpha+\beta \ln x+Z \gamma+\varepsilon
$$

where $s$ is the share of total expenditure allocated to a given category, $x$ represents total expenditure, $Z$ is a vector of covariates which includes the household size, number of children under eighteen years of age, number of earners in the household, urban, provincial and year dummy variables except for the reference categories $^{2}, \beta$ is the parameter of interest to be estimated, which allows to derive the elasticity of households expenditure in a given category with respect to total expenditures or permanent income. Finally, $\gamma$ is a vector of unknown parameters to be estimated, and $\varepsilon$ is an independently identically normally distributed error term with zero mean and standard deviation of $\sigma$.

The estimation of Equation (1) by OLS method is straight forward. The model is estimated for different expenditures categories that are related to children including, child care, school related, clothing, recreational activities and toys, and for different groups of households.

The estimated coefficients in this model are used to derive the elasticity of household expenditure on expenses in a given category with respect to total expenditures, which is the focus of this study. The concept of elasticity is impor${ }^{2} \mathrm{We}$ also included interactions between the dummies and the model parameters to allow these parameters to vary across year, however, these interaction effects were not statistically significant, which indicates that the model parameters are stable over the years of this study. 
tant in economic theory which estimates the percent change in the expenditure of a given category induced by a one percent change in total expenditure. ${ }^{3}$

To derive this elasticity recall that for a function $=g(x)$, the elasticity of $s$ with respect to $x$ can be expressed as follows:

$$
E_{s, x}=\frac{g^{\prime}(x) / g(x)}{x^{\prime} / x}=\frac{g^{\prime}(x) \cdot x}{g(x)}
$$

Since the share of total expenditure for a given category is defined as:

$$
s=\frac{e}{x}
$$

where $e$ represents the household expenditure in a given category, using Equation (2) and Equation (3) the elasticity of expenditure $e$ with respect to total expenditure $x$, can be expressed as follows:

$$
E_{e, x}=1+\frac{\beta}{\alpha+\beta \ln x+Z \gamma}
$$

\section{Estimation Results}

We first present a descriptive analysis and a set of comparison tests for a selection of expenditures and households types. We then present the estimates results of the Working-Leser model including expenditures elasticities.

\subsection{Descriptive Analysis Comparison Tests}

The first step in our analysis is a descriptive analysis of household's expenditures based on the 2015 and 2017 samples of CCB-eligible survey respondents.

A selection of these results is presented in Table 1. The first key observation from this table is that many groups who would be receiving some amount of CCB increased spending on recreational activities and toys.

As shown in Table 1, there is a significant increase in the proportion of households that spend any positive amount on recreational activities (such as recreational services, recreational equipment, vehicles and associated services) for couples with at least one child under eighteen or on toys for those likely receiving the full CCB, between 2015 to 2017. The increases in proportion of households spending some positive amount on toys are also observed when the sample includes only households with at least one child under eleven and with at least one child under six. There is also a significant increase in the proportion of couples spending some positive amount on recreational activities for couples with at least one child under eleven.

Households likely receiving the full CCB spent more on recreational activities and toys in 2017 compared to 2015, which could potentially be the result of the increased permanent income added by the receipt of the CCB, since these changes are either less pronounced for households receiving partial CCB or no CCB.

${ }^{3}$ This model was also used by Deaton and Muellbauer (1999) and Dudek (2011). 
Table 1. Selection of expenditure changes and results of a one-tailed comparison test.

\begin{tabular}{|c|c|c|}
\hline & 2015 & 2017 \\
\hline \multicolumn{3}{|l|}{ Couples likely receiving full CCB with at least one child $<18$ years old } \\
\hline Recreational activities (\% of households spending $>\$ 0$ ) & $20.38 \%$ & $39.80 \% * *$ \\
\hline Toys (\% of households spending $>\$ 0$ ) & $17.97 \%$ & $38.81 \%^{* *}$ \\
\hline \multicolumn{3}{|l|}{ Couples likely receiving full CCB with at least one child $<11$ years old } \\
\hline Recreational activities (\% of households spending $>\$ 0$ ) & $23.66 \%$ & $48.61 \%^{*}$ \\
\hline Toys (\% of households spending $>\$ 0$ ) & $20.19 \%$ & $45.36 \%$ ** \\
\hline Child care (Per child expenditure) & $\$ 292$ & $\$ 1428^{*}$ \\
\hline Child care ( $\%$ of households spending $>\$ 0$ ) & $14.98 \%$ & $35.04 \%^{*}$ \\
\hline \multicolumn{3}{|l|}{ Couples likely receiving full CCB with at least one child $<6$ years old } \\
\hline Toys (\% of households spending $>\$ 0$ ) & $26.94 \%$ & $58.41 \%^{* *}$ \\
\hline \multicolumn{3}{|l|}{ Couples likely receiving partial CCB with at least one child $<11$ years old } \\
\hline Child care (Per child expenditure) & $\$ 1504$ & $\$ 2367^{\star * *}$ \\
\hline Child care ( $\%$ of households spending $>\$ 0$ ) & $40.10 \%$ & $50.60 \%$ ** \\
\hline \multicolumn{3}{|l|}{ Couples likely receiving partial CCB with at least one child $<6$ years old } \\
\hline Child care (Per child expenditure) & $\$ 1854$ & $\$ 3093^{* * *}$ \\
\hline Child care ( $\%$ of households spending $>\$ 0$ ) & $46.73 \%$ & $55.92 \% *$ \\
\hline \multicolumn{3}{|l|}{ Single parents likely receiving full CCB with at least one child $<18$ years old } \\
\hline Food (Per child expenditure as a \% of total expenditure) & $11.10 \%$ & $6.92 \% \%^{* *}$ \\
\hline Out-of-pocket health (per child expenditure as a $\%$ of total expenditure) & $2.00 \%$ & $0.82 \%^{* * *}$ \\
\hline
\end{tabular}

Statistical significance is denoted as follows: ${ }^{* *}(0.01$ level $),{ }^{* *}(0.05$ level $),{ }^{*}(0.10$ level $)$. Source: Survey of Household Spending 2015, 2017.

Table 1 also reveals a significant increase in child care spending for CCB recipients with younger children following the introduction of the CCB. For couples with at least one child under eleven who would likely receive the full CCB, there is a statistically significant increases in 2017 compared to 2015, in both per child expenditure on child care, as well as the proportion of couples spending some positive amount on child care. For couples likely receiving partial CCB, there is also a significant increase in these same indicators for households with at least one child under eleven.

When considering only households with at least one child under six, there is a significant increase in the proportion of couples likely receiving the partially phased-out CCB spending some positive amount on child care expenses. A significant increase in the average amount spent on child care is also observed for those couples. These increases may indicate that child care spending is more of a priority for this group than for those receiving the full CCB. Alternately, this may represent an increase in the proportion of two-parent households with two working parents made possible by the CCB.

Finally, based on Engel's Law, there is a significant increase in household 
wellbeing for single parents who receive the $\mathrm{CCB}$, given the observed reduction in the share of some necessity goods in total expenditure that is not accompanied by a reduction in absolute term in these expenditures. Compared to 2015, there are significant drops in the share of expenditures related to food and out-of-pocket health expenses in 2017 for single parent households who would receive the full CCB. The fact that significant decreases in the proportions of these expenses in 2017 are observed for only the single parent households who would be receiving the full CCB likely indicates that this group has experienced the greatest increase in wellbeing.

\subsection{The Working-Leser Model and Elasticities Estimates}

The model estimation includes all households from 2010 to 2017 with at least one child under eighteen years old. The analysis is also conducted for single parents and couples with children for three groups based on the likelihood of receiving different amounts of CCB. Equation (4) is then used to derive the elasticities estimates. The standard errors of the elasticities are computed using the delta method. All the elasticities are statistically significant at the 0.05 level, except cleaning supplies and out-of-pocket health expenditures for couples with children likely receiving the full CCB.

Table 2 presents the estimated elasticities and show the results of a one-tailed test of the null hypotheses that the estimated elasticity is less than or equal to 1 or greater or equal to 1 , depending of the expenditure category ${ }^{4}$, with different levels of statistical significance.

These elasticities estimates represent the percent increase in expenditure in a given category induced by a one percent change in total expenditure or permanent income. For example, for couples with children that would likely be receiving the full CCB amount, a one percent increase in total expenditure would lead to a $1.56 \%$ increase in child care spending. An elasticity with a value smaller than one is associated with a necessity good or service, whereas an elasticity with a value greater than one indicate the presence of luxury or accessory good or service for which the demand is sensitive to any change in permanent income.

For both couples and single parents, food expenditure elasticities are less than one regardless of a household's portion of CCB received. This means that as family income increases, they will spend a lower share of total expenditure on food. Based on Engel's Law, this indicates an increased standard of living for these households. A similar fact is observed for clothing expenditure, indicating that clothing expenditures represent a necessity good. Alternately, shelter expenditure becomes more elastic as income increases, except for single parent households for which elasticities estimates are all below one.

Transportation spending elasticities for couples with children is relatively consistent at estimates greater than one, meaning that as total expenditure increases, ${ }^{4}$ The spending categories on child care, school-related, recreational activities, toys, and transportation are tested whether they are elastic (elasticity greater than 1), and the other categories are tested whether they are inelastic (elasticity less than 1). 
Table 2. Expenditure elasticity estimates and results of a one-tailed test.

\begin{tabular}{cccccc}
\hline & \multicolumn{3}{c}{ Couples with children } & \multicolumn{2}{c}{ Single parent households } \\
\cline { 2 - 6 } $\begin{array}{c}\text { Expenditure } \\
\text { Category }\end{array}$ & $\begin{array}{c}\text { Likely } \\
\text { Receiving } \\
\text { full CCB }\end{array}$ & $\begin{array}{c}\text { Likely } \\
\text { Receiving } \\
\text { partial CCB }\end{array}$ & $\begin{array}{c}\text { Likely } \\
\text { Receiving } \\
\text { no CCB }\end{array}$ & $\begin{array}{c}\text { Likely } \\
\text { Receiving } \\
\text { full CCB }\end{array}$ & $\begin{array}{c}\text { Likely } \\
\text { Receiving } \\
\text { partial CCB }\end{array}$ \\
\hline Child care & $1.561^{* * *}$ & $1.591^{* * *}$ & 1.090 & $1.718^{* * *}$ & 1.291 \\
School-related & 0.944 & $1.804^{* *}$ & $1.649^{* *}$ & $2.495^{*}$ & $2.085^{* *}$ \\
Toys & 1.371 & $1.257^{* *}$ & 0.632 & $1.894^{* *}$ & $2.324^{* *}$ \\
Recreational activities & $1.895^{* *}$ & $1.253^{* * *}$ & 0.884 & $2.004^{* * *}$ & 1.249 \\
Clothing & $0.812^{* *}$ & $0.730^{* * *}$ & $0.737^{* *}$ & $0.536^{* * *}$ & $0.692^{* *}$ \\
Food & $0.741^{* * *}$ & $0.641^{* * *}$ & $0.471^{* * *}$ & $0.764^{* * *}$ & $0.552^{* * *}$ \\
Shelter & $0.746^{* * *}$ & $0.814^{* * *}$ & 1.100 & $0.793^{* * *}$ & $0.758^{* * *}$ \\
Transportation & $1.477^{* * *}$ & $1.468^{* * *}$ & $1.335^{* * *}$ & $1.620^{* * *}$ & $1.501^{* * *}$ \\
Health & 0.524 & $0.539^{* * *}$ & $0.703^{* *}$ & 1.329 & 0.933 \\
Cleaning supplies & $0.165^{*}$ & $0.692^{* * *}$ & $0.710^{* *}$ & $0.779^{*}$ & 0.818 \\
\hline
\end{tabular}

Statistical significance is denoted as follows: ${ }^{* *}(0.01$ level $),{ }^{* *}(0.05$ level $),{ }^{*}(0.10$ level $)$. Source: Survey of Household Spending 2010-2017.

the share of expenditure that goes toward transportation expenses will also increase with a higher proportion. Elasticities for out-of-pocket health spending that are statistically significant are also much lower and less than one for couples with children (Figure 1).

For all households receiving full $\mathrm{CCB}$, child care expenditure elasticities are greater than one, indicating that this expenditure represents a luxury service which is sensitive to a change in household income. Child care spending is more elastic for couples receiving the full or partial CCB than for those not receiving $\mathrm{CCB}$, and also more elastic for single parents receiving full $\mathrm{CCB}$ than those receiving partial CCB. This may indicate these households have financial constraints that prevent them from maximizing their utility. Receiving CCB allows them to overcome these constraints and purchase child care services to be able to work more or to join the labour market if they are not already in it. It appears that child care services represent a relatively high priority for these households.

School spending for couples with children is by contrast more elastic for those receiving partial or no $\mathrm{CCB}$ than for those receiving the full $\mathrm{CCB}$, which suggests that spending on school-related items is a higher priority for those households than for those receiving the full CCB. For single parent households receiving some amount of the CCB have an elasticity for school spending that is statistically significantly greater than one, which indicates that these spending items are very sensitive to any change in household income, i.e. they represent a priority for those households.

Toys and recreational activities elasticities are generally statistically significantly greater than one, indicating that these services represent a luxury expenses for those households which are very sensitive to any change in household in- 
come. For couples with children, the elasticities of toy expenditures are only statistically significantly greater than one for those receiving partial CCB. However, recreational activity spending becomes less elastic as a household receives less CCB. For single parent households, toy expenditures are very elastic and increase as the portion of CCB likely received goes down, which means that these expenditures represent a high priority for these households as their income increases (Figure 2).

These elasticities estimated for groups receiving different levels of CCB help indicate which categories of expenditure act as basic expenses, as well as which are more spending priorities for couples with children or for single parent households. Together, these give an idea of where additional expenditure from the introduction of the CCB could be expected to go.

\section{Conclusion}

The objective of this study is to examine the effects of the Canada Child Benefit on family expenditures. Estimation of direct child benefit impact on household expenditure is challenging since benefit and household income may be endogenously determined, i.e. child benefit income increases households' unearned income and therefore may have an impact on labour supply decisions.

The proposed approach relies on the permanent income hypothesis and on Engel's law. Spending patterns vary by family composition and income, but overall results indicate that receipt of this benefit is associated with an increase in households' wellbeing.

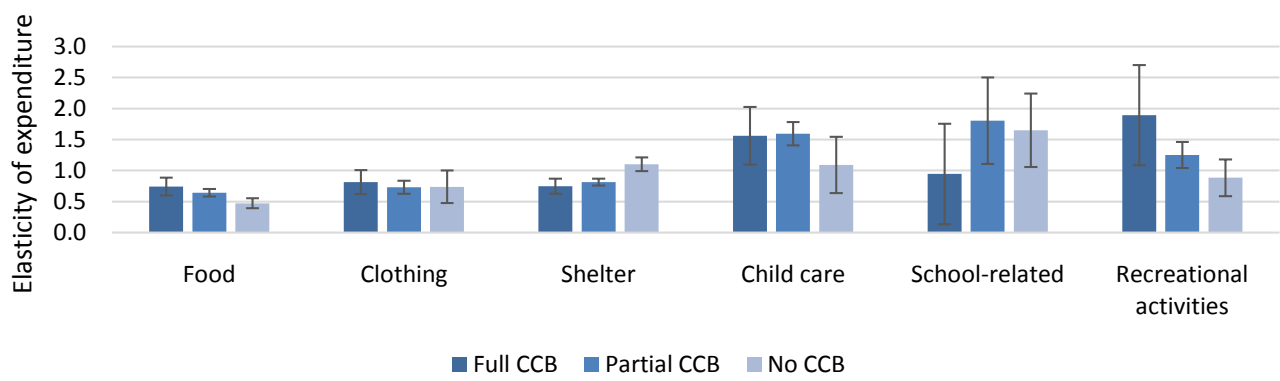

Figure 1. Elasticity of expenditure estimates for couples with children. $95 \%$ confidence intervals are plotted for the estimates. Source: Survey of Household Spending 2010-2017.

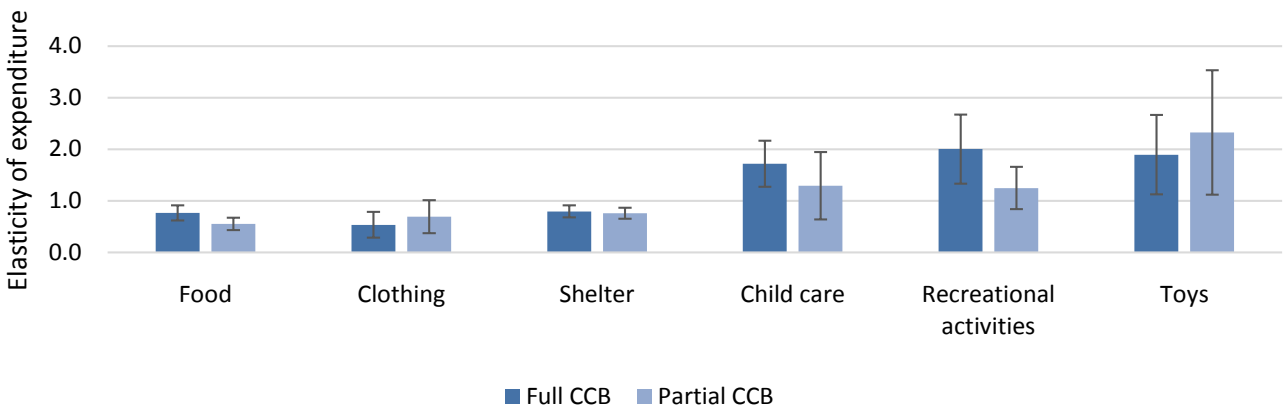

Figure 2. Elasticity of expenditure estimates for single parents. $95 \%$ confidence intervals are plotted for the estimates. Source: Survey of Household Spending 2010-2017. 
Based on the elasticities estimates, child care appears to be more of a spending priority for those who would be receiving higher amounts of CCB while school-related spending is more of a priority for couples with children who would be receiving lower amounts of CCB. This may indicate that those households have financial constraints that prevent them from maximizing their utility.

Additionally, based on Engel's Law, movements in the shares of food and clothing expenditures as well as shelter expenditure for single parents indicate that receipt of the $\mathrm{CCB}$ would improve the wellbeing of households who receive it.

\section{Acknowledgements}

The views expressed in this report are those of the authors and not necessarily those of Employment and Social Development Canada. We would like to thank Patrick Bussiere, Karen Hall, and the anonymous paper referees for useful comments. Finally, a special thanks to Krishan Suki Abeysekera, Bin Hu, and Sébastien Ivall for providing timely assistance with respect to data access to Statistics Canada's Research Data Centre.

\section{Conflicts of Interest}

The authors declare no conflicts of interest regarding the publication of this paper.

\section{References}

Bank of Canada (2017). Annual Report. https://www.bankofcanada.ca/wp-content/uploads/2018/03/annualreport2017.pdf

Barker, D. J. (1998). Mothers, Babies and Health in Adult Life. Edinburgh: Churchill Livingstone.

Bhargava, A. (2008). Food, Economics, and Health. Oxford: Oxford University Press. https://doi.org/10.1093/acprof:oso/9780199269143.001.0001

Black, S. E., Devereux, P. J., Løken, K. V., \& Salvanes, K. G. (2012). Care or Cash? The Effect of Child Care Subsidies on Student Performance. Review of Economics and Statistics, 96, 824-837. https://doi.org/10.3386/w18086

Braga, B., Blavin, F., \& Gangopadhyaya, A. (2019). The Long-Term Effects of Childhood Exposure to the Earned Income Tax Credit on Health Outcomes. IZA Discussion Papers No. 12417.

Brown, E. M., \& Tarasuk, V. (2019). Money Speaks: Reductions in Severe Food Insecurity Follow the Canada Child Benefit. Preventive Medicine, 129, Article ID: 105876. https://doi.org/10.1016/j.ypmed.2019.105876

Case, A., Fertig, A., \& Paxson, C. (2005). The Lasting Impact of Childhood Health and Circumstance. Journal of Health Economics, 24, 365-389. https://doi.org/10.1016/j.jhealeco.2004.09.008

Cunha, F., \& Heckman, H. (2007). The Technology of Skill Formation. The American Economic Review, 97, 31-47. https://doi.org/10.3386/w12840

Dahl, G., \& Lochner, L. (2012). The Impact of Family Income on Child Achievement: Evidence from the Earned Income Tax Credit. American Economic Review, 102, 1927-1956. https://doi.org/10.1257/aer.102.5.1927 
Deaton, A., \& Muellbauer, J. (1999). Economics and Consumer Behaviour. Cambridge: Cambridge University Press.

Department of Finance Canada (2018). Strengthening the Canada Child Benefit. Government of Canada.

Dudek, H. (2011). Quantitative Analysis of the Household's Expenditure for Food. Problems of World Agriculture, 26, 23-30.

Engel, E. (1857). Die productions-und consumtionsverhältnisse des königreichs sachsen. Zeitschrift des Statistischen Bureaus des Königlich Sächsischen Ministeriums des Innern, 8, 1-54.

Friedman, M. (1957). The Permanent Income Hypothesis. In A Theory of the Consumption Function (pp. 20-37). Princeton, NJ: Princeton University Press. https://doi.org/10.1515/9780691188485-005

Ginja, R. (2010). Income Shocks and Investments in Human Capital (Job Market Paper).

González, L. (2013). The Effect of a Universal Child Benefit on Conceptions, Abortions, and Early Maternal Labor Supply. American Economic Journal: Economic Policy, 5, 160-188.

Gregg, P., Waldfogel, J., \& Washbrook, E. (2006). Family Expenditures Post-Welfare Reform in the UK: Are Low-Income Families Starting to Catch Up? Labour Economics, 13, 721-746. https://doi.org/10.1016/j.labeco.2005.10.002

Hamad, R., \& Rehkopf, D. H. (2016). Poverty and Child Development: A Longitudinal Study of the Impact of the Earnted Income Tax Credit. American Journal of Epidemiology, 183, 775-784. https://doi.org/10.1093/aje/kwv317

Harding, A. (2018). The Effect of Government Transfer Programs on Low-Income Rates: A Gender-Based Analysis, 1996 to 2016. Ottawa: Statistics Canada.

Hoynes, H., Miller, D., \& Simon, D. (2015). Income, the Earned Income Tax Credit, and Infant Health. American Economic Journal: Economic Policy, 7, 172-211. https://doi.org/10.1257/pol.20120179

Jones, L. E., Milligan, K., \& Stabile, M. (2019). Child Cash Benefits and Family Expenditures: Evidence from the National Child Benefit. Canadian Journal of Economics.

Kooreman, P. (2000). The Labeling Effect of a Child Benefit System. American Economic Review, 90, 571-583. https://doi.org/10.1257/aer.90.3.571

Leser, C. E. (1963). Forms of Engel Functions. Econometrica, 31, 694-703. https://doi.org/10.2307/1909167

Milligan, K., \& Stabile, M. (2011). Do Child Tax Benefits Affect the Wellbeing of Children? Evidence from Canadian Child Benefit Expansions. American Economic Journal: Economic Policy, 3, 175-205. https://doi.org/10.1257/pol.3.3.175

Tominey, E. (2010). The Timing of Parental Income on Child Outcomes: The Role of Permanent and Transitory Shocks (Job Market Paper).

Working, H. (1943). Statistical Laws of Family Expenditure. Journal of the American Statistical Association, 38, 43-45. https://doi.org/10.1080/01621459.1943.10501775 


\section{Annex A: Expenditure Categories Examined}

\begin{tabular}{ll}
$\begin{array}{l}\text { Expenditure category and } \\
\text { variables included: }\end{array}$ & Description: \\
\hline Child care & $\begin{array}{l}\text { Includes child care outside the home and child care in the home } \\
\text { Includes spending on clothing for children fourteen years old and } \\
\text { under }\end{array}$ \\
Clothing & $\begin{array}{l}\text { Includes tuition fees for kindergarten, elementary, and secondary } \\
\text { schools, and school supplies }\end{array}$ \\
School-related & $\begin{array}{l}\text { Includes spending on children's camps and other courses and } \\
\text { lessons i.e. music, dancing, sports, crafts }\end{array}$ \\
Recreational activities & $\begin{array}{l}\text { Includes spending on children's toys, outdoor play equipment and } \\
\text { accessories, video game systems and accessories, and art and craft } \\
\text { materials }\end{array}$ \\
Toys & $\begin{array}{l}\text { Includes food purchased from stores and food purchased from } \\
\text { restaurants }\end{array}$ \\
Food & $\begin{array}{l}\text { Includes all expenditure for principal accommodation and other } \\
\text { accommodations }\end{array}$ \\
Shelter & $\begin{array}{l}\text { Includes total direct costs to households for health care } \\
\text { Includes household cleaning supplies and equipment }\end{array}$ \\
Out-of-pocket health expenses & Includes spending on public and private transportation \\
Transportation &
\end{tabular}

